\title{
Source Identification of Emission Sources for Hydrocarbon with Backward Trajectory Model and Statistical Methods
}

\author{
Tai-Yi Yu* \\ Department of Risk Management and Insurance, Ming Chuan University, Taipei, Taiwan
}

Received: 26 July 2016

Accepted: 9 October 2016

\begin{abstract}
Several statistical techniques were combined with a backward trajectory model and emission inventory to locate sources of total hydrocarbon (THC) emissions and to calculate contributed ratios of emission sources. Emission attraction, a novel method of combining emission inventory and residence time, was introduced to confirm respective contributions of specific emission sources with detailed meteorological and emissions data. This research combined four techniques - residence time, conditional probability function, emission inventory and principal component analysis - to locate possible regions and sources on severe surface ozone episodes and non-episode days. Temporal and spatial interpolation manners were performed on surface and rawinsonde meteorological stations, and complex terrain effects were corrected with a variation-kinematic model. Emission inventory of THC and maximum incremental reactivity (MIR) scales were utilized to calculate the accounted contributions of distinct emission sources from various jurisdictions. Conditional probability function combined with emission attraction could reveal potential regions that emitted high THC emissions and MIR scales during ozone episodes.

The ratios of emission attraction for 11-h backward trajectories indicated that $68 \%$ of THC emissions and $74 \%$ of MIR scales were from the target air-quality basin during non-episode days; the respective figures during ozone episodes were $81 \%$ and $75 \%$. The combination of emission attraction and conditional probability function could identify specific locations that cause severe ground ozone pollution and provide more detailed information about source regions compared to traditional RTA and PSCF approaches.
\end{abstract}

Keywords: residence time, emission attraction, conditional probability function, MIR scale

\section{Introduction}

The formation of ground-level ozone, or secondary air pollutants [1], can be simulated with photochemical [2-5], artificial neural network [6-7], trajectory [8-9] and receptor

\footnotetext{
*e-mail: yutaiyi@gmail.com
}

models [10-11]. For making rapid strategic decisions when assessing abatement strategies of air-quality management programs for ground-level ozone, an approach linked with trajectory models and statistical methods could be a more effective approach than photochemical models. Trajectory models are widely used in air pollution-related studies to determine the cause-effect relationship between sources and receptors, to identify potential sources in accordance with elevated concentrations of air pollutants [12-14], and 
to find correlations between potential sources of $\mathrm{PM}_{10}$ and specific transport pathways that exist at high $\mathrm{PM}_{10}$ levels [6, 15-17]

The backward trajectory-based statistical approaches used to identify the accounted contribution of emission sources to air quality or to explore the cause-effect relationship between emission sources and receptors include residence time analysis (RTA), potential source contribution function (PSCF), conditional probability function (CPF), redistributed concentration fields (RCF), and concentration fields $(\mathrm{CF})$. Researchers have applied the RTA approach to identify source regions of air pollutants [18], trace source regions of fine particulate matter [19], locate emission sources of ozone precursors [20], and evaluate potential long-range transport impacts on particulate matter [21]. The use of PSCF improved the estimation of cause-effect relationships between gaseous mercury and 14 chemical species found in precipitation [22], located fugitive sources in industrial facilities [23], investigated possible locations of major sources on $\mathrm{PM}_{10}$ and $\mathrm{PM}_{25}[11,24-26]$, confirmed the sources of aerosol transported from serious polluted regions [27], and explored possible sources of non-methane hydrocarbons [28]. Studies of grid cells with high CF values reveal that air parcels passing through these cells result in high concentrations at receptor sites [23, 29-30]. Zhu et al. [16] and $\mathrm{Li}$ et al. [31] applied PSCF and CF approaches to trace potential sources of $\mathrm{PM}_{10}$ in Beijing and Shanghai, respectively. Wang et al. [32] identified anthropogenic sources of aerosol over the East China Sea with PSCF and positive matrix factorization manners. The CPF and PSCF manners effectively recognized regions where the airflows have high potential for elevating pollutant concentrations [33-34] and identified $\mathrm{PM}_{2.5}$-emitted sources [35].

Setting the concentration of air pollutants on a single trace as a unique value may underestimate concentration gradients during long-term trace analysis. Stohl [36] specified RCF instead of measured concentrations and split a single trajectory into several segments within one hour. Scheifinger and Kaiser [37] attempted to validate three trajectory-based statistical techniques - PSCF, CF, and $\mathrm{RCF}$ - with virtual and real sources of $\mathrm{SO}_{2}$ emission inventory. Salvador et al. [38] utilized the RCF method and cluster analysis to recognize potential source regions of key aerosol components. Moreover, Cheng et al. [39] utilized the concentration weighted trajectory (CWT) model (a combination of concentration and residence time) and CPF to identify potential sources of atmospheric mercury; Squizzato and Masiol [40] applied CWT, CPF, and PSCF techniques to understand the influence of external and local contributions of $\mathrm{PM}_{2.5}$ sources. Some studies applied PSCF and CWT models to identify spatial source distributions of $\mathrm{OC}, \mathrm{EC}$, and $\mathrm{PM}_{2.5}$ [41], and investigate transport pathways and potential source areas of $\mathrm{PM}_{2.5}$ in different seasons [42].

Ground-level ozone results from the interaction of emitted oxides of nitrogen (NOx) and hydrocarbon with sufficient sunlight. When measuring hydrocarbon emissions, measuring the contribution of hydrocarbon compounds to ozone formation is essential; one approach to presenting ozone formation is incremental reactivity index. The concept of VOC reactivity may introduce quantification of the relative importance of ozone formation potentials (reactivity). Maximum incremental reactivity (MIR) [43] is the primary reactivity scale used in VOC-limited conditions in California (1990), and is applied in reference scenarios consisting of specified meteorological conditions such as initial concentrations and emission rates of NOx and VOC.

Trajectory-based statistical methods that apply RTA, PSCF, CPF, CF, and RCF techniques have proven useful for identifying pathways of air parcels and possible emission sources over continent regions. The above methods can indicate specific locations in which air pollutants are likely to cause high concentrations. However, they cannot reveal the locations of emission sources that cause severe air pollution. In coastal regions and the sea, concentrations of air pollutants cannot be measured by stationary monitoring stations. Therefore, approaches that consider the $\mathrm{CF}$ or RCF of air pollutants cannot identify regions that are potential sources of ozone pollution. This study combined three factors of emission attraction, emission rate, and residence time in a screen method of interpreting potential regions of deteriorated air quality, and evaluated the contribution ratios of various sources and regions. The combination of emission attraction and CPF were also proposed to indicate specific source regions with high emission attraction over ozone episodes.

This study had the following objectives.

1) Determine the spatial distribution of ratios on residence time.

2) Evaluate the relative accounted ratios of emission attraction from distinct jurisdictions and sources for THC emission and MIR scales.

3) Calculate the conditional probability of emission attraction for THC emission and MIR scales.

\section{Material and Methods}

The Taiwan Environmental Protection Administration (EPA) has divided the geographic area of Taiwan into seven air-quality basins. Kaoping air-quality basin has exhibited the largest deterioration in air quality since 1993. During 1998-2007, the annual probability of PSI above 100 (unhealthy air-quality) was $6.7-13.4 \%$ in the Kaoping air-quality basin, which was much higher than the 2.6-5.1\% probability for all of Taiwan. The two major causes of unhealthy air-quality over Kaoping air-quality basin were $\mathrm{PM}_{10}$ and ozone. The violating rates of one hour standard of ozone were $0.5-0.8 \%, 7.9-40.6 \%$ for a daily eight-hour standard of ozone, and 4.2-18.3\% for a daily standard for $\mathrm{PM}_{10}$ over Kaoping air-quality basin in 1998-2007.

The objective of the Taiwan EPA air-quality management program is to reduce the ratios of unhealthy air pollutants; therefore, this study investigated the locations and types of potential sources of elevated 
ozone levels. In the past decade (2005-14), the highest exceeding rates of eight-hour average ozone concentration were $8.9 \%$ in 2007 and $10.0 \%$ in 2009 over Taiwan. The baseline year for estimating and revising emission inventory of 2007 and 2009 was the year 2007 [44], and the target year of metrological data was determined as year 2007 accordingly. Kaoping air-quality basin has been identified as the most ozone-polluted district over Taiwan since 1993, and a VOC-limited region [45] was chosen as the target region. This research established cause-effect relationships for ozone precursors over the Kaoping airquality basin by using statistical methods, backward trajectory models, and emission inventory during ozone episodes. The selection of ozone episodes, backward trajectory model, RTA, emission attraction, and CPF used in this study are described in the following sections.

\section{Ozone Episode Selection}

Principal component analysis identifies the independent principal components of variation within a large, interrelated data set by reducing the dimensionality of complex variables. The data used for principal component analysis was the maximum hourly $\mathrm{O}_{3}$ values obtained from air-quality monitoring stations in the Kaoping airquality basin in 1998-2007. The data can be viewed as a collection of time sequences with 14 vectors (14 stations x 3652 days). Ozone episodes were determined with the mean component scores of the unrotated first principal component [46]. Station number (average occurrence of exceeding ozone hourly standard per station) is treated as an index for achieving the goal of developing an air quality management strategy in Taiwan. If a maximum 1-h ozone concentration measured at one station exceeds $120 \mathrm{ppb}$ in a day, then the station number is 1 ; two stations exceed $120 \mathrm{ppb}$ in a day and the station number is 2 . In contrast to ozone episodes, two months in spring and autumn (the first two seasons with high ozone levels over Taiwan) in 2007 were classified as non-episode days.

The relationship between the standardized $Z$ value and the unrotated principal component analysis is described as Eq. (1):

$$
\mathrm{Z}_{i k=} \sum_{j=1}^{n} L_{i j} P_{j k}
$$

... where $Z_{\text {ik }}$ refers to the $K^{\text {th }} Z$ value in station $I, L_{i j}$ refers to the factory loading of the $\mathrm{J}^{\text {th }}$ principal component at station $\mathrm{I}, \mathrm{P}_{\mathrm{jk}}$ refers to the score of the $\mathrm{J}^{\text {th }}$ principal component of the $\mathrm{K}^{\text {th }}$ variable, and $\mathrm{n}$ refers to the number of stations. The average component scores of the first principal component can be obtained by deriving the reverse vector of Eq. (1) as shown in Eq. (2):

$$
Q_{1 k}=\frac{1}{n} \sum_{i=1}^{n} \frac{L_{i 1} \times Z_{i k}}{\lambda_{1}}
$$

...where $\mathrm{Q}_{1 \mathrm{k}}$ refers to the $\mathrm{K}^{\text {th }}$ component scores of the first unrotational principal component. The first principal component represents the maximum variance of $\mathrm{O}_{3}$ concentrations of all principal components.

\section{Backward Trajectory Model}

Construction of the backward trajectory model in this study started at the air-quality station and traced the changing position of the air parcels at a backward time step along with wind flow. The wind fields modelled with Mesoscale Model 5 (MM5) and Weather Research and Forecasting (WRF) models over complex terrain were less accurate than over flat terrain because of complex terrain and highly variable surface roughness [47]. This study therefore applied the assimilation method to avoid overestimating surface wind velocity because it objectively interpolates spatial values. A variationalkinematic model [48] was also used to correct for the effects of complex terrain. The meteorological data were categorized as ground and rawinsonde meteorological data. Hourly ground meteorological data were obtained from 25 stations affiliated with the Central Weather Bureau (CWB) and 57 air-quality monitoring stations operated by the Taiwan EPA (Fig. 1). The surface and airsonde meteorological data measured by the Taiwan CWB were used to establish hourly three-dimensional wind speed data at horizontal grid cells. Air quality was then calculated by backward tracing of data from all airquality stations located in the Kaoping air-quality basin. Horizontal wind flow 200 meters above surface was also calculated as the representative wind speed of air parcels.

\section{Residence Time Analysis}

Residence time was used to evaluate potential regions in which air parcels of backward trajectories would appear and to define the cumulative time during which air mass traces remained in a grid cell. The higher the residence time, the higher the probability of wind flows through a specific grid cell. Backward tracing started from the time of the maximum ozone concentration within a day period and ended 72 hours later, and the time step was one sec. Taiwan is 394 kilometers long and 144 kilometers wide, therefore the distance of travelling 72 hours with $1.5 \mathrm{~m} \mathrm{sec}^{-1}$ (slow wind speed) for air parcels exceeds 388 kilometers. The lengths of Taiwan ratios of residence time could be estimated as Eq. (3):

$$
\begin{aligned}
& \operatorname{Re}_{i j}=\frac{\tau_{i j}}{\sum_{i j} \tau_{i j}} \\
& \tau_{i j}=\sum_{k} T_{i j k}
\end{aligned}
$$

...where $\operatorname{Re}_{i j}$ is the ratio of residence time at cell $l_{\mathrm{ij}}$ to all cells; $\tau_{i j}$, $\mathrm{hr}$, is the cumulative residence time of cell $_{\mathrm{ij}}$; and $\mathrm{T}_{i j k}, \mathrm{hr}$, is the residence time of cell $\mathrm{ij}_{\mathrm{j}}$ for trace $\mathrm{k}$. 


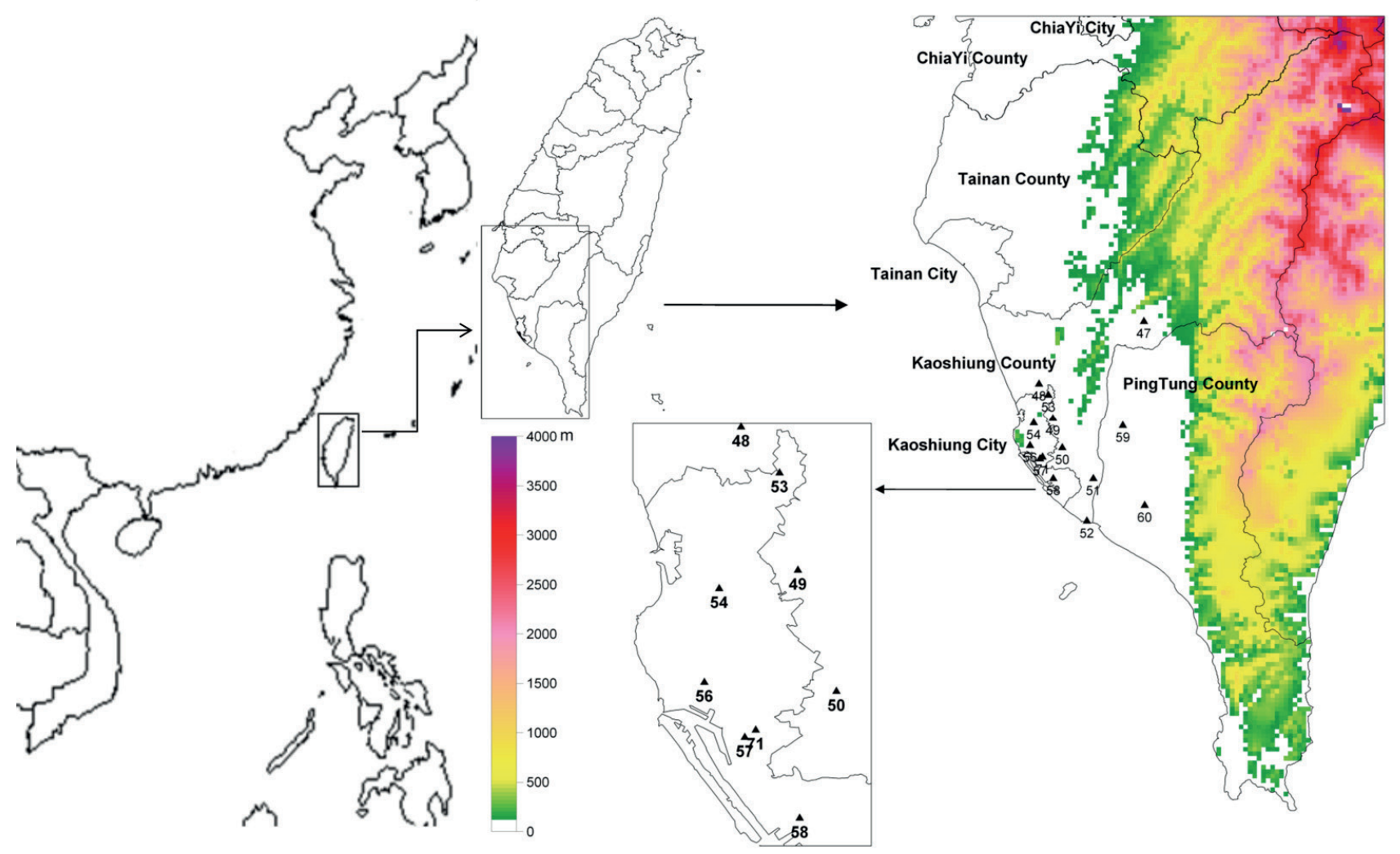

Fig. 1. Topography and locations of air-quality monitoring stations.

\section{Emission Attraction}

Emission attraction is the product of emission rate and residence time that describes the emissions emitted for a specific cell over a period of time. This term could be utilized to evaluate potential source regions and emission contributions for specific scenarios. Emission rates of THC emissions and MIR scales could also be considered. This approach attempts to compare the accounted ratios of emission attraction between ozone episodes and nonepisode days and to identify attributed percentages of THC emissions and MIR scales over various jurisdictions. Hourly emission inventory is categorized into stationary lines and area sources, and the size of individual cells used in analysis of line and area sources is $1 \times 1 \mathrm{~km}$. Based on THC emissions in the Taiwan Emission Database System [44], this database only covered emission sources over Taiwan, and stationary sources refer to stationary combustion sources and industrial processes while line sources refer to the emission of on-road and off-road vehicular sources. Finally, area sources are mainly fugitive emissions such as those produced by surface coatings, construction, solvent evaporation, and commercial use. Emission attraction is calculated using Eq. (4).

$$
E n_{i j}=\sum_{k} E_{i j k t} \times T_{i j k}
$$

... where $\mathrm{En}_{\mathrm{ij}}$ and $\mathrm{kg}$ represent emission attraction of THC emissions or MIR scales on cell $\mathrm{ij}_{\mathrm{ij}}$, and $\mathrm{E}_{\mathrm{ijkt}}$ and $\mathrm{kg} \mathrm{hr}^{-1}$ denote emission rates at $\mathrm{t}^{\text {th }}$ hour for $\mathrm{k}^{\text {th }}$ trace on cell $\mathrm{ij}_{\mathrm{ij}}$. In contrast to photochemical models, emission attraction is a simplified and screen alternative for assessing the relative contribution of specific sources or effectiveness of control strategies before constructing complex photochemical models; however, emission attraction requires the following data:

- Correct and detailed emission inventory.

- Representative wind flow field.

- Statistically representative receptors and trajectories. The analysis also makes the following assumptions:

- No chemical reaction and precipitation.

- Complete mixing in an individual cell.

- No downward mixing for concentration of air pollutants.

\section{Conditional Probability of Emissions Attraction}

The conditional probability of emission attraction, which indicates the high levels of emission attraction during ozone episodes, can be expressed as Eq. (5):

$$
P\left[B_{i j} \mid A_{i j}\right]=\frac{P\left[B_{i j} \cap A_{i j}\right]}{P\left[A_{i j}\right]}
$$


...where the $\mathrm{P}\left[\mathrm{B}_{\mathrm{ij}} \mid \mathrm{A}_{\mathrm{ij}}\right]$ represents the probability of event $B$ occurring under the circumstances of event A. In this study, event A was the emission attraction of THC emissions on cell ${ }_{\mathrm{ij}}$ on non-episode days and event $\mathrm{B}$ was the emission attraction of THC emissions on cell ${ }_{\mathrm{ij}}$ during ozone episodes. The conditional probability can be simplified as Eq. (6):

$$
P\left[B_{j} \mid A_{j}\right]=\frac{P\left[B_{j}\right]}{P\left[A_{j}\right]}
$$

The widely used PSCF value represents the conditional probability of an air parcel passing through cell ${ }_{i, j}$, elevating the concentration at the receptor site [26]. A high PSCF value indicates high probability that the cell is the emitted sources. Grid cells with high conditional probability of emission attraction indicate a high probability of air parcels passing through these cells with high emission attraction during ozone episodes; not presented is these cells having a high source contribution to high levels of air pollutants.

\section{Results and Discussion}

Analytical results of principal component analysis revealed that the eigenvalue and explained contribution of the first unrotated component were 10.1 and $72.3 \%$, and then 1.2 and $8.7 \%$ for the second unrotated principal component. Fig. 2 plots the relationship between component scores for the first component and stationnumber of ozone. Mean component scores for the first component were greater than 1.4 , and station-number value was 6.5 and covered $46 \%$ of stations. Simply stated, since the first component score exceeded 1.4, the maximum 1-h ozone of $46 \%$ of stations exceeded 120 ppb over the Kaoping air-quality basin. According to this criterion, ozone episodes comprised $7.0 \%$ of days and

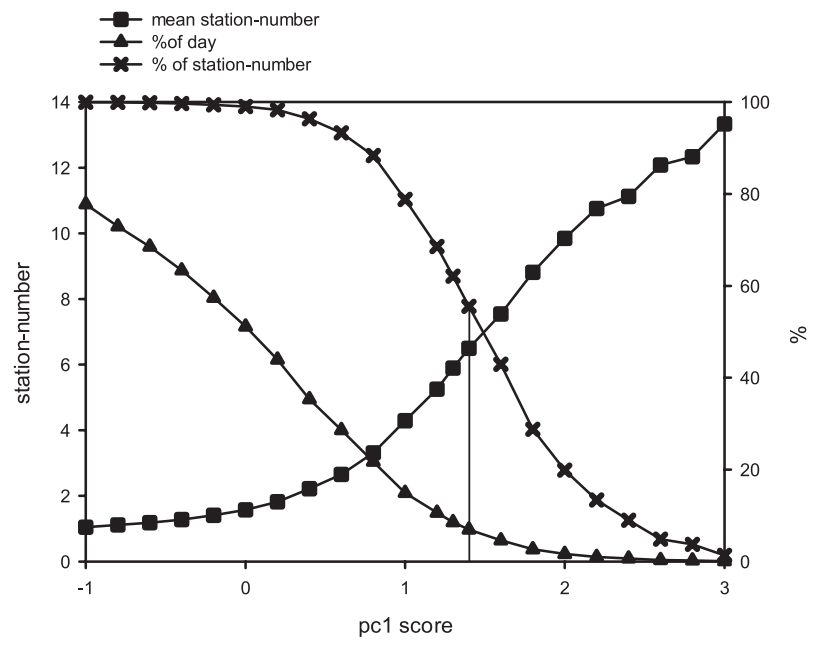

Fig. 2. Relationship between average component scores of the first principal component and station-number.
$55.6 \%$ of total station-number values in 1998-2007. The ozone episodes and non-episode days cited in 2007 were 30 and 182 days, respectively.

In Kaoping air-quality basin, maximum hourly $\mathrm{O}_{3}$ occurs at 12:00-17:00. The morning non-methane hydrocarbon (NMHC)/NOx ratio (AM 6-9) was usually used to calculate ozone isopleths, therefore time length of backward traveling could be 6-11 hours. Figs 3a-b show the residence time maps generated while traveling six and 11 hours on non-episode days, respectively. Residence time for a specific cell $(1 \times 1 \mathrm{~km})$ was calculated as the ratio of cumulative time during which air parcels remained at a specific cell to cumulative time across the domain. Although residence time over a specific area indicates general flow patterns, it does not indicate its contribution to air pollutant concentrations at a receptor site since it does not account for emissions and concentrations. High ratios of residence time focused on three jurisdictions, regions $\mathrm{KSC}$, KST, and TNT, and the sea area off Kaoping airquality basin. The ratios of residence time when traveling sic and 11 hours were 43.6 and 33.7\%, respectively, over the sea area off Kaoping air-quality basin during nonepisode days. Therefore, the preceding area has a major contribution to residence time. The use of residence time analysis to locate potential sources of air pollution may underestimate the contributions of emission sources on land because of high ratios of residence time over sea areas. Low ratios of residence time over eastern Taiwan indicated low contributions of emission sources from eastern Taiwan during non-episode days. The prevailing winds in Taiwan are strong northeasterly winds in winter, southwesterly winds in summer, and weak northeasterly winds in autumn. The wind direction is in transition during spring. The sea-land breezes in southern Taiwan play a dominant role in spatial distribution of air pollutants and transport of air pollutants. Weak sea winds cause polluted air parcels to stagnate at elevated THC emission regions and form high ozone pollution in the $\mathrm{KSC}$ and KST districts.

The THC emission density in various jurisdictions (Table 1) revealed specific features of distinct emission

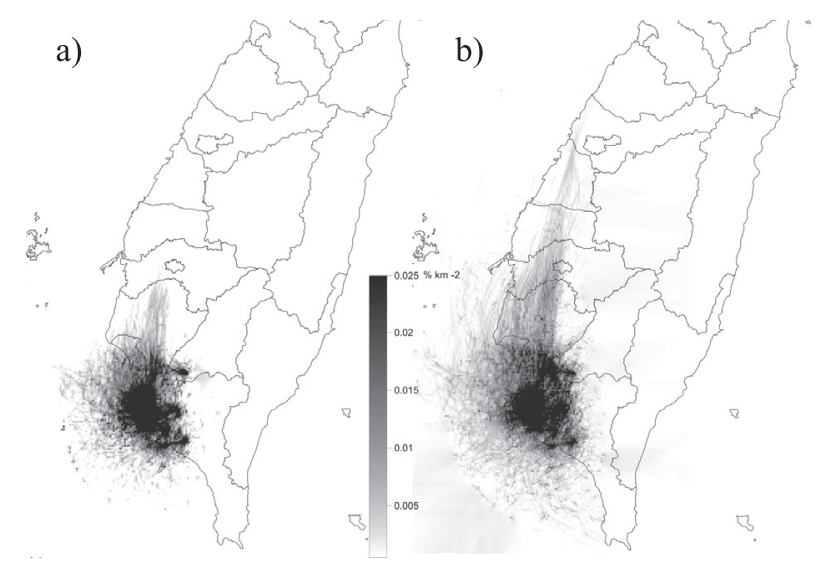

Fig. 3. Ratios of residence time when traveling a) six and b) 11 hours during non-episode days. 
Table 1. Anthropogenic THC emission densities over various political districts.

\begin{tabular}{|c|c|c|c|c|c|c|c|c|c|c|}
\hline \multirow{2}{*}{ Political districts } & \multicolumn{3}{|c|}{ Area } & \multicolumn{2}{|c|}{ Emission density (tons $\left.\mathrm{yr}^{-1} \mathrm{~km}^{-2}\right)$} & \multicolumn{4}{c|}{ Ratio (\%) } \\
\cline { 2 - 12 } & $\mathrm{Km}^{2}$ & Ratio $(\%)$ & Point & Line & Area & Sum & Point & Line & Area & Sum \\
\hline ChiaYi County, CYT & 1902 & 5.3 & 3.8 & 1.9 & 10.0 & 11.9 & 0.9 & 0.5 & 2.4 & 3.8 \\
\hline ChiaYi City, CYC & 60 & 0.2 & 8.4 & 37.7 & 136.1 & 173.8 & 0.1 & 0.3 & 1.1 & 1.4 \\
\hline Tainan County, TNT & 2016 & 5.6 & 5.5 & 4.7 & 15.4 & 20.1 & 1.4 & 1.2 & 4.0 & 6.7 \\
\hline Tainan City, TNC & 176 & 0.5 & 10.2 & 35.4 & 37.5 & 73.0 & 0.2 & 0.8 & 0.9 & 1.9 \\
\hline Kaoshiung County, KST & 2793 & 7.8 & 5.3 & 4.2 & 9.5 & 13.7 & 1.9 & 1.5 & 3.4 & 6.8 \\
\hline Kaoshiung City, KSC & 154 & 0.4 & 125.9 & 102.7 & 160.2 & 262.8 & 2.5 & 2.0 & 3.2 & 7.7 \\
\hline Pingtung County, PTT & 2776 & 7.7 & 0.8 & 2.5 & 4.0 & 6.6 & 0.3 & 0.9 & 1.4 & 2.6 \\
\hline Kaoping Air Basin & 5,723 & 15.9 & 6.4 & 6.0 & 10.9 & 23.3 & 4.7 & 4.5 & 8.0 & 17.2 \\
\hline Taiwan & 36,000 & 100.0 & 4.3 & 4.8 & 12.4 & 21.5 & 19.8 & 22.5 & 57.7 & 100.0 \\
\hline
\end{tabular}

sources. Comparing local and national THC emissions, regions KSC, KST, and Tainan County (TNT) generated the three highest emission ratios $(7.7,6.8$, and $6.7 \%$ for all sources; $2.5,1.9$, and $1.4 \%$ for stationary sources and $3.2,3.4$, and $4.0 \%$ for area sources, respectively). The KSC region had the highest THC emission densities, 125.9, 102.7 and 160.2 tons $\mathrm{yr}^{-1} \mathrm{~km}^{-2}$ for stationary, line, and area sources, respectively. The KSC region is a highly industrialized and commercialized district and had the largest city in southern Taiwan. Spatial emission densities for THC and NOx are described in Figs 4(a, b).

Table 2 presents emission density of MIR scales for various jurisdictions. Three regions - KST, and KSC, and TNT - also generated the three highest concentrations of MIR scales at 7.7, 7.1, and $6.2 \% ; 2.2,1.7$, and $1.1 \%$ for stationary sources; and 3.7, 3.0, and 3.7\% for area sources, respectively. The highest emission density is 156.6, 228.7, and 283.4 tons $\mathrm{yr}^{-1} \mathrm{~km}^{-2}$ for stationary, line, and area sources, respectively, in the KSC region. Since MIR scales of vehicular emission exceeded area and stationary sources, line sources had the highest ratios. a)

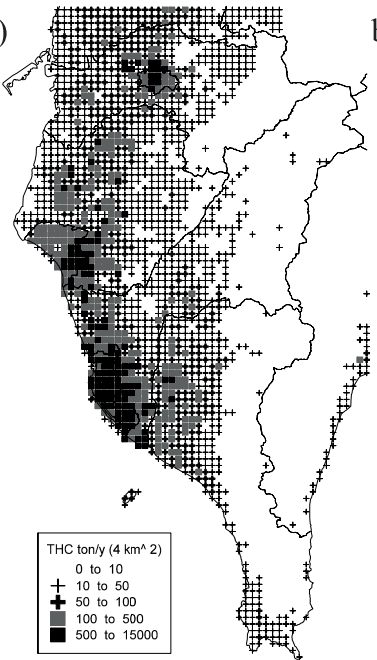

b)

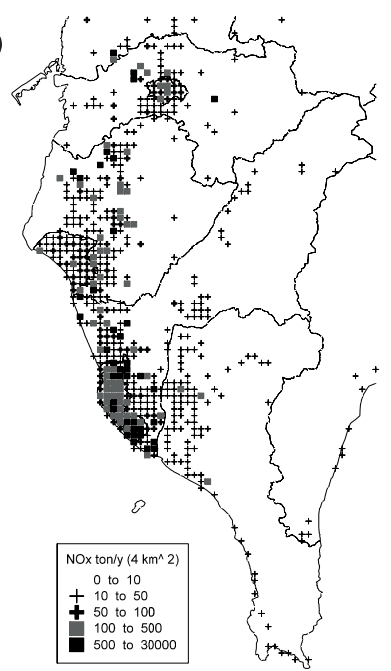

Fig. 4. Spatial emission intensity of a) THC and b) NOx.
The analysis of emission attraction on THC emission and MIR scales also obtained the accounted ratios for three emission patterns (stationary, line, and area sources) and for distinct jurisdictions. The ratios of THC emission and MIR scales from Kaoping air-quality basin were 17.2 and $17.7 \%$, respectively. Figs $5(\mathrm{a}, \mathrm{b})$ show the ratios for emission attraction of $\mathrm{THC}$ emissions when traveling six and 11 hours over the Kaoping air-quality basin during non-episode days. High ratios of emission attraction on THC emission were observed in the KSC, KST, and TNT regions and in Tainan City (TNC). The covered area of high ratios of emission attraction for 11-h trajectories was larger than that for the 6-h trajectories because of the longer traveling time and prevailing northeasterly winds.

The 11-h backward trajectories showing contribution ratios of $\mathrm{THC}$ emission attraction (Table 3) of Kaoping air-quality basin were $68.1 \%$ for non-episode days and $74.3 \%$ for MIR scales, 18.4 and $17.2 \%$ for stationary sources, 16.4 and $20.9 \%$ for line sources, and 33.3 and $36.1 \%$ for area sources. The KST region presented the highest ratio of THC emission attraction (40.3\%) and MIR scales (48.0\%) during non-episode days. Considering the objective of controlling THC emissions during non-episode days, the regions' sources should be prioritized as area sources in KST, point sources in $\mathrm{KST}$, and line sources in KSC. Area sources in KST were recognized as the primary target because the contribution ratio was $3.4 \%$ of emissions and $23.3 \%$ for emission attraction; 2.5 and $13.3 \%$ for the second target, stationary source in KST.

Figs 6(a, b) plot emission attraction and ratios for emission attraction with MIR scales, respectively, when traveling six and 11 hours during non-episode days in 2007. The accounted ratios of emission attraction had higher values for vehicular emissions in MIR scales than THC emissions. Figs 6(a, b) show that the line-like shapes were easily identifiable. Similarly, high ratios of emission attraction on MIR scales focused in the four regions: KSC, KST, TNT, and TNC. 
Table 2. Potential ozone production densities over various political districts.

\begin{tabular}{|c|c|c|c|c|c|c|c|c|}
\hline \multirow{2}{*}{ Political districts } & \multicolumn{3}{|c|}{$\begin{array}{c}\text { Potential ozone production density } \\
\text { (tons } \mathrm{yr}^{-1} \mathrm{~km}^{-2}\end{array}$} & \multicolumn{4}{|c|}{ Ratio (\%) } \\
\cline { 2 - 12 } & Point & Line & Area & Sum & Point & Line & Area & Sum \\
\hline ChiaYi County, CYT & 5.7 & 4.2 & 21.1 & 31.0 & 0.7 & 0.6 & 2.8 & 4.1 \\
\hline ChiaYi City, CYC & 9.9 & 84.4 & 290.5 & 384.8 & $<0.1$ & 0.4 & 1.2 & 1.6 \\
\hline Tainan County, TNT & 7.5 & 10.4 & 26.2 & 44.2 & 1.1 & 1.4 & 3.7 & 6.2 \\
\hline Tainan City, TNC & 17.4 & 81.2 & 48.4 & 147.0 & 0.2 & 1.0 & 0.6 & 1.8 \\
\hline Kaoshiung County, KST & 11.2 & 9.5 & 19.4 & 40.1 & 2.2 & 1.8 & 3.7 & 7.7 \\
\hline Kaoshiung City, KSC & 156.6 & 228.7 & 283.4 & 668.6 & 1.7 & 2.4 & 3.0 & 7.1 \\
\hline Pingtung County, PTT & 1.6 & 5.6 & 7.6 & 14.8 & 0.3 & 1.1 & 1.5 & 2.8 \\
\hline Kaoping Air Basin & 10.5 & 13.5 & 20.7 & 44.7 & 4.1 & 5.4 & 8.2 & 17.7 \\
\hline Taiwan & 6.8 & 10.9 & 22.5 & 40.1 & 16.8 & 27.2 & 55.9 & 100.0 \\
\hline
\end{tabular}

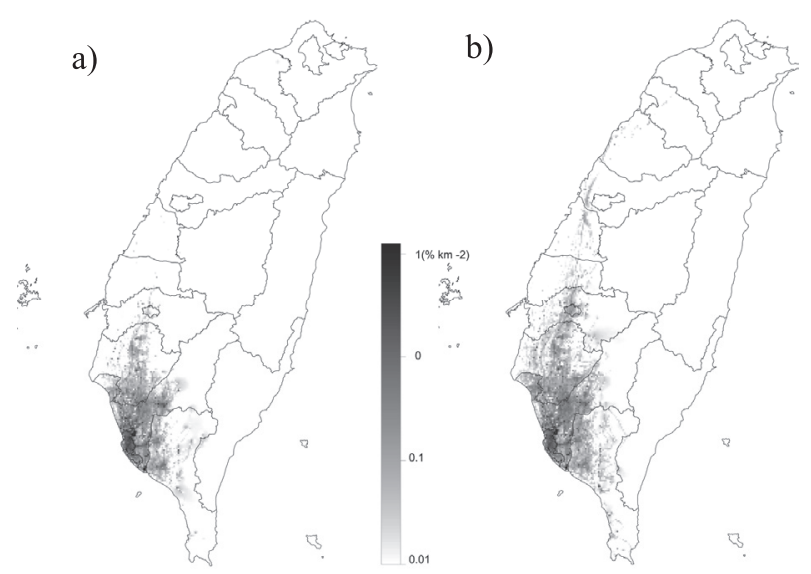

Fig. 5. Ratios of emission attraction of THC emissions when traveling a) six and b) 11 hours during non-episode days.

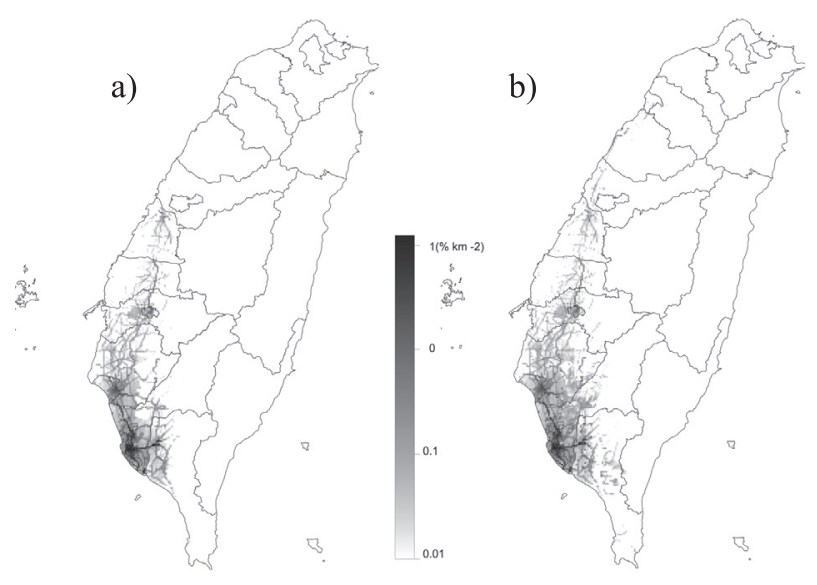

Fig. 6. Ratios of emission attraction of potential ozone production when traveling a) six and b) 11 hours during non-episode days.

Table 3. Ratios of emission attractions when traveling 11 hours during non-episode days.

\begin{tabular}{|c|c|c|c|c|c|c|c|c|}
\hline \multirow{2}{*}{ Political districts } & \multicolumn{4}{|c|}{ THC (\%) } & \multicolumn{4}{c|}{ MIR (\%) } \\
\cline { 2 - 10 } & Point & Line & Area & Sum & Point & Line & Area & Sum \\
\hline ChiaYi County, CYT & 0.2 & 0.3 & 1.7 & 2.3 & 0.2 & 0.4 & 2.1 & 2.7 \\
\hline ChiaYi City, CYC & 0.1 & 0.2 & 0.3 & 0.5 & $<0.1$ & 0.2 & 0.3 & 0.6 \\
\hline Tainan County, TNT & 2.0 & 1.2 & 13.0 & 16.2 & 1.6 & 1.5 & 12.6 & 15.7 \\
\hline Tainan City, TNC & 0.3 & 1.6 & 0.5 & 2.3 & 0.3 & 2.1 & 0.4 & 2.7 \\
\hline Kaoshiung County, KST & 13.3 & 3.8 & 23.3 & 40.3 & 15.9 & 4.9 & 27.2 & 48.0 \\
\hline Kaoshiung City, KSC & 4.9 & 11.1 & 3.4 & 19.5 & 3.5 & 14.1 & 3.5 & 21.1 \\
\hline Pingtung County, PTT & 0.3 & 1.5 & 6.5 & 8.3 & 0.3 & 1.9 & 7.0 & 9.2 \\
\hline Kaoping Air Basin & 18.4 & 16.4 & 33.3 & 68.1 & 17.2 & 20.9 & 36.1 & 74.3 \\
\hline Taiwan & 21.8 & 20.7 & 57.5 & 100.0 & 21.7 & 25.1 & 53.1 & 100.0 \\
\hline
\end{tabular}


Table 4. Ratios of emission attraction when traveling 11 hours during ozone episodes.

\begin{tabular}{|c|c|c|c|c|c|c|c|c|}
\hline \multirow{2}{*}{ Political districts } & \multicolumn{4}{|c|}{ THC $(\%)$} & \multicolumn{5}{c|}{ MIR (\%) } \\
\cline { 2 - 10 } & Point & Line & Area & Sum & Point & Line & Area & Sum \\
\hline ChiaYi County, CYT & 0.1 & 1.1 & 0.4 & 1.6 & 0.1 & 1.1 & 0.4 & 1.6 \\
\hline ChiaYi City, CYC & $<0.1$ & $<0.1$ & 0.1 & 0.1 & $<0.1$ & $<0.1$ & 0.1 & 0.1 \\
\hline Tainan County, TNT & 2.4 & 11.2 & 5.9 & 19.4 & 1.5 & 11.1 & 4.5 & 17.0 \\
\hline Tainan City, TNC & 0.1 & 4.5 & 0.2 & 4.9 & 0.1 & 4.7 & 0.1 & 4.9 \\
\hline Kaoshiung County, KST & 10.0 & 15.3 & 12.7 & 38.0 & 9.5 & 15.5 & 11.7 & 36.7 \\
\hline Kaoshiung City, KSC & 4.9 & 26.0 & 6.2 & 37.1 & 2.7 & 26.0 & 4.9 & 33.7 \\
\hline Pingtung County, PTT & 0.1 & 4.9 & 1.2 & 6.2 & 0.1 & 4.9 & 1.0 & 6.0 \\
\hline Kaoping Air Basin & 15.0 & 46.3 & 20.1 & 81.4 & 11.1 & 46.5 & 17.2 & 74.7 \\
\hline Taiwan & 17.6 & 64.0 & 18.4 & 100.0 & 13.9 & 63.4 & 22.7 & 100.0 \\
\hline
\end{tabular}

Analysis of 11-h backward trajectories of ozone episodes showed that the KST region (Table 4) had the highest contribution ratios of emission attraction on THC emissions and MIR scales. In region KST, the accounted ratios of emission attraction for stationary sources were $10.0 \%$ for THC emissions and $9.5 \%$ for MIR scales; 15.3 and $15.5 \%$ for line sources; and 12.7 and $11.7 \%$ for area sources. Line sources in the KSC region had the highest ratio of emission attraction and the highest density of roads over Kaoping air-quality basin. The three priority targets for controlling THC emissions during ozone episodes were line sources in $\mathrm{KSC}$ and $\mathrm{KST}$, and point sources in KST. The accounted ratios and emission attraction on THC emission were 2.0 and $26.0 \%$, respectively, for line sources in KSC, which was the first target; 1.5 and $15.3 \%$ for line sources in KST, which was the second target. Contribution ratio of emission attraction for line sources in the KSC region were evidently the highest in southern Taiwan because of the highest density of roads.

During non-episode days, the KST region had the highest accounted ratios of emission attraction for THC emission (40.3\%) and MIR scales (48.0\%); 13.3 and 15.9\% for stationary sources; and 23.3 and $27.2 \%$ for area sources. Eventually, contribution ratios of emission attraction from line and area sources for THC fell below those of MIR scales over regions $\mathrm{KSC}$ and KST. The KST region had the highest ratio of emission attraction for THC emissions (38.0\%) and MIR scales (36.7\%) during ozone episodes. The 11-h backward trajectories showed that the ratio of emission attraction for THC emission was $68.1 \%$ on nonepisode days and $81.4 \%$ during ozone episodes over the Kaoping air-quality basin; for MIR scales, the respective figures were 74.3 and $74.7 \%$. The largest contributors to air pollution were the Kaoping air-quality basin itself based on 11-h backward trajectories of non-episode days and ozone episodes. The ratios of emission attraction for THC emissions and MIR scales on line source during ozone episodes were higher than those observed on non-episode days; stationary sources showed opposite correlation. Reducing vehicular emissions in regions KSC and KST should be dominant abatement strategies according to the emission attraction of MIR scales observed during ozone episodes. Analysis of the emission attraction of MIR scales revealed that the accounted ratios of vehicular emissions were higher than those of THC emissions in stationary and area sources. The use of emission attraction could identify relative contributions for emission sources from various jurisdictions.

Conditional probability of emission attraction could provide spatial data for specific regions needed to explain high percentages of emission attraction during ozone episodes. The higher conditional probability of emission attraction for an individual cell, the higher the probability of a cell absorbing emission attraction during ozone episodes. High conditional probability values for emission attraction on emissions of THC emission (Fig. 7a) and MIR scale (Fig. 7b) were observed in the 11-h trajectories for the KSC and KST regions. Conditional probabilities of emission attraction on THC emissions had
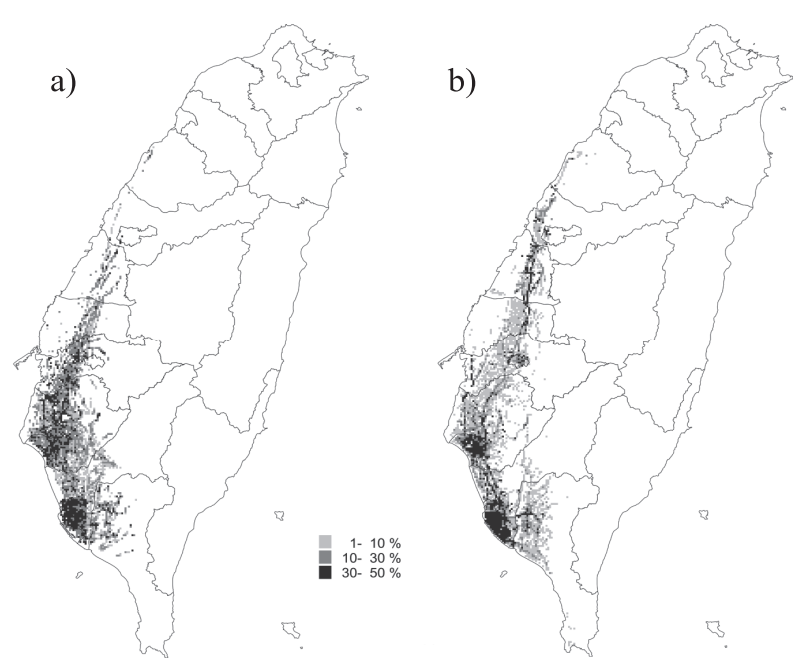

Fig. 7. Conditional probability values on emission attraction of a) THC emission and b) potential ozone production when traveling 11 hours. 
high values over the KSC, KST, TNT, and TNC regions; and regions KSC and TNC for MIR scales. The weak sea breeze effect, upwind emission sources, and locations of monitoring stations are the major causes of ozone episodes over the Kaoping air-quality basin. The analyses of emission attraction and conditional probability of emission attraction on MIR scales demonstrated that the major contributor to ozone episodes in the KSC, KST, and TNC regions was vehicular traffic on major roads.

\section{Conclusions}

This study evaluated the effects of source-receptor relationships on emissions of THC and MIR scales in terms of several backward trajectory-based techniques, RTA, CPF, and emissions attraction. Emission attraction could be a simplified approach for obtaining detailed data for specific emission sources that contribute to deteriorated air-quality and for providing accounted ratios of emission attraction. The application of emission attraction and CPF could be a useful approach for identifying locations and contributions of source regions during air pollution episodes. The trajectory-based statistical manners used in this study could be screen alternatives or useful techniques for evaluating the cause-effect relationship between emission sources and receptors for specific air pollutants with correct and detailed information of meteorological, emission inventory, and measured air pollutant concentrations.

The analysis of emission attraction and conditional probability function for ozone episodes in Kaoping airquality basin demonstrated the dominant sources that should have a high priority in reducing NMHC emissions were vehicular sources on major roads in the KSC, KST, TNT, and TNC regions. Analyzing emission attraction could provide more detailed data about regions and sources compared to analysis of residence time and PSCF over coastal regions. It also avoids the need to calculate emissions and concentrations of air pollutants over the sea. The uncertainties of trajectories (locations of receptors and wind field) and emission inventory could diminish the accuracy and precision of emission attraction. With the manner of emission attraction, the location of potential sources that result in elevated air pollution could be further identified with detailed categories of specific sources.

\section{Acknowledgments}

The author would like to thank Taiwan's National Science Council for financially supporting this research under Contract No. NSC 93-2211-E-267-003.

\section{References}

1. VIJAYARAGHAVAN K., CHO S., MORRIS R., SPINK D., JUNG J., PAULS R., DUFFETT K. Photochemical model evaluation of the ground-level ozone impacts on ambient air quality and vegetation health in the alberta oil sands region: using present and future emission scenarios. Atmos. Environ. 141, 209, 2016.

2. CHING J., MAJEED M.A. An approach to characterize within-grid concentration variability in air quality models. Atmos. Environ. 49, 348, 2012.

3. FOLEY K.M., NAPELENOK S.L., JANG C., PHILLIPS S., HUBBELL B.J., FULCHER C.M. Two reduced form air quality modeling techniques for rapidly calculating pollutant mitigation potential across many sources, locations and precursor emission types. Atmos. Environ. 98, 283, 2014.

4. FOLEY K.M., HOGREFE C., POULIOT G., POSSIEL N., ROSELLE S.J., SIMON H., TIMIN B. Dynamic evaluation of CMAQ part I: Separating the effects of changing emissions and changing meteorology on ozone levels between 2002 and 2005 in the eastern US. Atmos. Environ. 103, 247, 2015 a.

5. FOLEY K.M., DOLWICK P., HOGREFE C., SIMON H., TIMIN B., POSSIEL N. Dynamic evaluation of CMAQ part II: Evaluation of relative response factor metrics for ozone attainment demonstrations. Atmos. Environ. 103, 188, 2015b.

6. PASCHALIDOU A.K., KASSOMENOS P., KARANIKOLA P. Disaggregating the contribution of local dispersion and long-range transport to the high $\mathrm{PM}_{10}$ values measured in a Mediterranean urban environment. Sci. Total Environ. 527528, 119, 2015.

7. PIRES J.C.M., ALVIM-FERRAZ M.C.M, PEREIRA M.C., MARTINS F.G. Prediction of $\mathrm{PM}_{10}$ concentrations through multi-gene genetic programming. Atmos. Pollut. Res. 1 (4), 305, 2010.

8. CHENG H.R., SAUNDERS S.M., GUO H., LOUIE P.K.K., JIANG F. Photochemical trajectory modeling of ozone concentrations in Hong Kong. Environ. Pollut. 180, 101, 2013a.

9. LING Z.H., GUO H., ZHENG J.Y., LOUIE P.K.K., CHENG H.R., JIANG F. , CHEUNG K., WONG L.C., FENG X.Q. Establishing a conceptual model for photochemical ozone pollution in subtropical Hong Kong. Atmos. Environ. 76, 208, 2013.

10. LUNA A.S., PAREDES M.L.L., de OLIVEIRA G.C.G., CORREA S.M. Prediction of ozone concentration in tropospheric levels using artificial neural networks and support vector machine at Rio de Janeiro, Brazil. Atmos. Environ. 98, 98, 2014.

11. LI J., YANG W., WANG Z., CHEN H., HU B., LI J., SUN Y., FU P., ZHANG Y. Modeling study of surface ozone sourcereceptor relationships in East Asia. Atmos. Res., 167 (1), 77, 2016.

12. RIUTTANEN L., HULKKONEN M., MASO M.D., JUNNINEN H., KULMALA M. Trajectory analysis of atmospheric transport of fine particles, $\mathrm{SO}_{2}, \mathrm{NO}_{\mathrm{x}}$ and $\mathrm{O}_{3}$ to the SMEAR II station in Finland in 1996-2008. Atmos. Chem. Phys. 13 (4), 2153, 2013.

13. OH H.-R., HO C.-H., KIM J., CHEN D., LEE S., CHOI Y.S., CHANG L.-S., SONG C.-K. Long-range transport of air pollutants originating in China: A possible major cause of multi-day high-PM10 episodes during cold season in Seoul, Korea. Atmos. Environ. 109, 23, 2015.

14. SCHWARZ J., CUSACK M., KARBAN J., CHALUPNÍČKOVÁ E., HAVRÁNEK V., SMOLÍK J., ŽDÍMAL V. PM $_{2.5}$ chemical composition at a rural background site in Central Europe, including correlation and air mass back trajectory analysis. Atmos. Res. 176-177, 108, 2016. 
15. MAKRA L., MATYASOVSZKY I., GUBA Z., KARATZAS K., ANTTILA P. Monitoring the long-range transport effects on urban $\mathrm{PM}_{10}$ levels using 3D clusters of backward trajectories, Atmos. Environ. 45, 2630, 2011.

16. 16.ZHU L., HUANG X., SHI H., CAI X., SONG Y. Transport pathways and potential sources of $\mathrm{PM}_{10}$ in Beijing. Atmos. Environ. 45, 594, 2011.

17. 17.KONG X., HE W., QIN N., HE Q., YANG B., OUYANG H., WANG Q., XU F. Comparison of transport pathways and potential sources of $\mathrm{PM}_{10}$ in two cities around a large Chinese lake using the modified trajectory analysis. Atmos. Res. 122, 284, 2013.

18. ASHBAUGH L.L., MALM W.C., SADEH W.Z. A residence time probability analysis of sulfur concentrations at Grand Canyon National Park. Atmos. Environ. 19, 1263, 1985.

19. CHALBOT M.-C., MCELROY B., KAVOURAS I.G. Sources, trends and regional impacts of fine particulate matter in southern Mississippi valley: significance of emissions from sources in the gulf of Mexico coast. Atmos. Chem. Phys. 13 (7), 3721, 2013.

20. COMRIE A.C. Tracking Ozone: Air mass trajectories and pollutant source regions influencing ozone in Pennsyvania Forests. Ann. Assoc. Am. Geogr. 84 (4), 635, 1994.

21. DIMITRIOU K., KASSOMENOS P. Decomposing the profile of pm in two low polluted German cities - mapping of air mass residence time, focusing on potential long range transport impacts. Environ. Pollut. 190, 91, 2014.

22. LUCEY D., HADJIISKI L., HOPKE P.K., SCUDLARK J.R., Church T. Identification of sources of pollutants in precipitation measured at the mid-Atlantic US coast using potential source contribution function. Atmos. Environ. 35, 3979, 2001

23. BRERETON C.A., JOHNSON M.R. Identifying sources of fugitive emissions in industrial facilities using trajectory statistical methods. Atmos. Environ. 51, 46, 2012.

24. KARNAE S., JOHN K. Source apportionment of fine particulate matter measured in an industrialized coastal urban area of south Texas. Atmos. Environ. 45, 3769, 2011.

25. WANG Z., WU T., SHI G., FU X., TIAN Y., FENG Y., WU X., WU G., BAI Z., ZHANG W. Potential source analysis for $\mathrm{PM}_{10}$ and $\mathrm{PM}_{25}$ in autumn in a Northern City in China. Aerosol Air Qual. Res. 12, 39, 2012.

26. WANG L., LIU Z., SUN Y., JI D., WANG Y. Long-range transport and regional sources of $\mathrm{pm}_{2.5}$ in Beijing based on long-term observations from 2005 to 2010 . Atmos. Res. 157, 37, 2015

27. DI GILIO A., DE GENNARO G., DAMBRUOSO P., VENTRELLA G. An integrated approach using high timeresolved tools to study the origin of aerosols. Sci. Total. Environ. 530-531, 28, 2015.

28. CHOI E., CHOI K., YI S.M. Non-methane hydrocarbons in the atmosphere of a Metropolitan City and a background site in South Korea: Sources and health risk potentials. Atmos. Environ. 45, 7563, 2011.

29. KABASHNIKOV V.P., CHAIKOVSKY A.P., TUCSERA T.L., METELSKAYA N.S. Estimated accuracy of three common trajectory statistical methods. Atmos. Environ. 45, 5425,2011

30. DIMITRIOU K., REMOUNDAKI E., MANTAS E., KASSOMENOS P. Spatial distribution of source areas of $\mathrm{PM}_{25}$ by Concentration Weighted Trajectory (CWT) model applied in $\mathrm{PM}_{25}$ concentration and composition data. Atmos. Environ. 116, 138, 2015

31. LI M., HUANG X., ZHU L., LI J, SONG Y., CAI X., XIE $\mathrm{S}$. Analysis of the transport pathways and potential sources of PM10 in Shanghai based on three methods. Sci.Total Environ. 414, 525, 2012.

32. WANG F., CHEN Y., MENG X., FU J., WANG B. The contribution of anthropogenic sources to the aerosols over east China sea. Atmos. Environ. 127, 22, 2016.

33. BEGUM B.A., BISWAS S.K., MARKWITZ A., HOPKE P.K. Identification of sources of fine and coarse particulate matter in Dhaka, Bangladesh. Aerosol Air Quality Res. 10, 345,2010

34. VESTENIUS M., LEPPÄNEN S., ANTTILA P., KYLLÖNENK., HATAKKAJ., HELLÉN H., HYVÄRINEN A.P., HAKOLA H. Background concentrations and source apportionment of polycyclic aromatic hydrocarbons in south-eastern Finland. Atmos. Environ. 45, 3391, 2011.

35. CHOI J.K., HEO J.B., BAN S.J., YI S.M., ZOH K.D. Source apportionment of $\mathrm{PM}_{2.5}$ at the coastal area in Korea. Sci. Total Environ. 447, 370, 2013

36. STOHL A. Trajectory statistics-a new method to establish source-receptor relationships of air pollutants and its application to the transport of particulate sulfate in Europe. Atmos. Environ. 30, 579, 1996.

37. SCHEIFINGER H., KAISER A. Validation of trajectory statistical methods. Atmos. Environ. 39, 8846, 2007.

38. SALVADOR P., ARTINANO B., PIO C., AFONSO J., LEGRAND M., PUXBAUM H., HAMMER S. Evaluation of aerosol sources at European high altitude background sites with trajectory statistical methods. Atmos. Environ. 44, 2316, 2010.

39. CHENG I., ZHANG L., BLANCHARD P., DALZIEL J., TORDON R. Concentration-weighted trajectory approach to identifying potential sources of speciated atmospheric mercury at an urban coastal site in Nova Scotia, Canada. Atmos. Chem. Phys. 13, 6031, 2013b.

40. SQUIZZATO S., MASIOL M. Application of meteorologybased methods to determine local and external contributions to particulate matter pollution: A case study in Venice (Italy). Atmos. Environ. 119, 69, 2015.

41. JEONG U., KIM J., LEE H., JUNG J., KIM Y. J., SONG C.H., KOO J.-H. Estimation of the contributions of long range transported aerosol in East Asia to carbonaceous aerosol and PM concentrations in Seoul, Korea using highly time resolved measurements: a PSCF model approach. J. Environ. Monit. 13 (7), 1905, 2011.

42. ZHAO M., HUANG Z., QIAO T., ZHANG Y., XIU G., YU J. Chemical characterization, the transport pathways and potential sources of $\mathrm{PM}_{25}$ in Shanghai: Seasonal variations. Atmos. Res. 158-159, 66, 2015.

43. CARTER W.P.L. Updated maximum incremental reactivity and hydrocarbon bin reactivities for regulatory applications. California Air Resources Board Contract 07-339, 2010.

44. TAIWAN ENVIRONMENTAL PROTECTION ADMINISTRATION. Taiwan Emission Database System (version 7.1), 2011.

45. CHEN T.F., CHANG K.H. Formulating the relationship between ozone pollution features and the transition value of photochemical indicators. Atmos. Environ. 40, 1816, 2006.

46. YU T.Y., CHANG L.F.W. Selection of the scenarios of ozone pollution at southern Taiwan area utilizing principal component analysis. Atmos. Environ. 34, 4499, 2000.

47. TARTAKOVSKY D., STERN E., BRODAY D.M. Evaluation of modeled wind field for dispersion modeling. Atmos. Res. 166, 150, 2015

48. YU T.Y., LIN T.Y., CHANG L.F.W.,Estimating air pollutant emission factors from open burning of rice straw by the residual mass method. Atmos. Environ. 54, 42, 2012. 